\title{
Investigation of Escherichia coli Fumarate Reductase Subunit Function Using Transposon Tn5
}

\author{
By DAVID J. LATOUR AND JOEL H. WEINER* \\ Department of Biochemistry, University of Alberta, Edmonton, Alberta, Canada T6G $2 \mathrm{H} 7$
}

(Received 2 July 1986; revised 4 September 1986)

\begin{abstract}
Seventy two $\operatorname{Tn} 5$ transposon insertions were isolated in the frd operon carried on the multicopy plasmid pFRD79. The polar nature of these mutations permitted examination of the expression and localization of the $f r d$ polypeptides in novel subunit combinations. The minimal catalytic unit is the FRDA plus B dimer. A transposon within $f r d B(f r d B:: \operatorname{Tn} 5)$ produces inactive, soluble FRDA polypeptide which has covalently attached $8 \alpha(N 3$-histidyl)flavin adenine dinucleotide cofactor. A transposon mutation within frdC (frdC::Tn5) produces soluble, catalytically active dimer. An insertion in $f r d D(f r d D:: \operatorname{Tn} 5)$ produces both a soluble trimer composed of FRDABC, and a tetramer of FRDABC and truncated FRDD bound to the inner membrane. Eighty percent of the activity is in the soluble form. Using this mutant, the requirement for FRDD both for optimal activity of the catalytic domain and for proper anchorage in the cytoplasmic membrane was demonstrated.
\end{abstract}

\section{INTRODUCTION}

When the facultative anaerobe Escherichia coli is grown anaerobically on medium containing glycerol and fumarate, a simple electron transport chain consisting of the anaerobic glycerol-3phosphate dehydrogenase, menaquinone, a $b$-type cytochrome and fumarate reductase is synthesized and assembled in the cytoplasmic membrane (Singh \& Bragg, 1975; Haddock \& Jones, 1977; Ingledew \& Poole, 1984). Fumarate reductase, the terminal electron transfer enzyme, is composed for four non-identical subunits of $69,27,15$, and $13 \mathrm{kDa}$ (Weiner et al., 1984), encoded by the $f r d A, B, C$ and $D$ genes, respectively. The $f r d$ operon has been cloned into multicopy plasmids and sequenced (Cole, 1982; Cole et al., 1982; Grundström \& Jaurin, 1982). Strains of $E$. coli harbouring such plasmids amplify fumarate reductase activity in their membranes 5-20-fold (Lohmeier et al., 1981; Weiner et al., 1984).

The holoenzyme has been purified and characterized (Weiner et al., 1984). The $69 \mathrm{kDa}$ polypeptide (FRDA) contains a catalytically essential sulphydryl group (Robinson \& Weiner, 1982 ) and a covalently bound $8 \alpha(N 3$-histidyl)flavin adenine dinucleotide cofactor (Weiner \& Dickie, 1979). The $27 \mathrm{kDa}$ subunit contains three iron-sulphur centres (Cole et al., 1982, 1986; Ingledew \& Poole, 1984; Cammack et al., 1986). Together these two subunits comprise a membrane-extrinsic catalytic domain which can be purified in water-soluble form (Dickie \& Weiner, 1979).

The 15 and $13 \mathrm{kDa}$ subunits (FRDC and FRDD, respectively) are basic and extremely hydrophobic in amino acid composition (Weiner et al., 1984). They form the membrane-anchor domain of fumarate reductase (Lemire et al., 1982). The finding that anions or the anchor polypeptides could stabilize the catalytic dimer against denaturation by either alkali $(\mathrm{pH}>8.6)$ or heat $\left(>45^{\circ} \mathrm{C}\right)$ has led to the proposal that the FRDC and D polypeptides have at least two functions: those of anchoring and stabilizing the catalytic dimer (Robinson \& Weiner, 1982; Lemire et al., 1982, 1983).

Abbreviations: GF, glycerol-fumarate medium; $\mathrm{DMNH}_{2}$, reduced 2,3-dimethyl-1,4-naphthoquinone. 
In E. coli, transposon $\mathrm{Tn} 5$ confers resistance to the aminoglycoside antibiotics kanamycin and neomycin (Berg et al., 1978). It transposes at high frequency (Johnson et al., 1982) and with little or no insertional specificity (Shaw \& Berg, 1979; Berg et al., 1980; Miller et al., 1980). Transposition of Tn 5 into a structural gene causes insertional inactivation, which is normally polar on cistrons located promoter-distal to the site of the insertion (Berg, 1977; Berg et al., 1980). Tn 5 mutagenesis has been used to generate correlated physical and genetic maps of DNA segments cloned into multicopy plasmids (Laird \& Young, 1980; Pannekoek et al., 1980; De Bruijn \& Ausubel, 1981; Lupski et al., 1982; De Bruijn et al., 1983).

In this paper Tn5 is used to introduce polar mutations into the plasmid-borne frd genes. The altered gene products are examined in terms of the known properties of fumarate reductase and the specific functions of individual polypeptides are discussed.

\section{METHODS}

Enzymes and chemicals. Restriction endonucleases EcoRI, AvaI, AluI and SalI were obtained from Boehringer. BamHI and HindIII were from Pharmacia. Rabbit anti-succinyl-CoA synthetase IgG was a gift from W. A. Bridger (this department). 2,3-Dimethyl-1,4-naphthoquinone was a gift from A. Kröger (J. W. Goethe University, Frankfurt, FRG). All other chemicals were of the highest grade commercially available.

Strains and plasmids. These are described in Table 1. pFRD79 is similar to pFRD63 (Lemire et al., 1982) except that the $4.5 \mathrm{kbp}$ HindIII fragment carrying the frd operon is reversed in orientation relative to the EcoRI site of pBR322. Expression of the frd operon is not altered by this change (data not shown).

Cell growth. Cells were grown anaerobically for $21 \mathrm{~h}$ on glycerol-fumarate medium (GF) supplemented with appropriate antibiotics, as described by Spencer \& Guest (1974).

Tn5 mutagenesis and plasmid isolation. $\mathrm{HB} 101$ (pFRD79) was grown overnight at $37^{\circ} \mathrm{C}$ on L-broth (Miller, 1972) supplemented with $20 \mu \mathrm{g}$ thiamin $\mathrm{ml}^{-1}, 10 \mathrm{mM}^{-} \mathrm{MgSO}_{4}$ and $100 \mu \mathrm{g}$ ampicillin ml ${ }^{-1} . \lambda b 221 \mathrm{cI} 857 \mathrm{rex}:: \operatorname{Tn} 5\left(3 \times 10^{9}\right.$ p.f.u.) was added to $6 \times 10^{8}$ cells of bacterial culture. The culture was incubated for $30 \mathrm{~min}$ at $24^{\circ} \mathrm{C}$, then centrifuged for $5 \mathrm{~min}$ at $13000 \mathrm{~g}$. The pellet was resuspended in $10 \mathrm{vols} \mathrm{L}$-broth containing thiamin and ampicillin, and the cells were incubated at $30^{\circ} \mathrm{C}$ without shaking for $2 \mathrm{~h}$. The cells were harvested as before, then resuspended in $200 \mu \mathrm{l}$ of medium. Samples $(100 \mu \mathrm{l})$ of the suspension were spread on L-broth agar plates supplemented with thiamin, ampicillin and $40 \mu \mathrm{g}$ kanamycin $\mathrm{ml}^{-1}$ and incubated overnight at $32^{\circ} \mathrm{C}$. Resistant colonies were suspended in $2 \mathrm{ml}$ of medium and $250 \mu \mathrm{l}$ was inoculated into $25 \mathrm{ml} \mathrm{L}$-broth containing thiamin and ampicillin and grown to stationary phase. Samples $(5 \mathrm{ml}$ ) of stationary phase culture were inoculated into $11 \mathrm{M} 9$ medium (Miller, 1972) with suitable supplements and plasmid DNA was amplified by the method of Clewell \& Helinski (1972). Cells were harvested and plasmid DNA was prepared as described by Lohmeier et al. (1981). HB101 cells treated with $\mathrm{CaCl}_{2}$ (Mandel \& Higa, 1970) were transformed with plasmid DNA and Tn5-containing plasmids were selected on L-broth plates supplemented with thiamin, ampicillin and kanamycin.

Screening Tns insertions. Individual colonies were picked and grown overnight at $37^{\circ} \mathrm{C}$ in $2 \mathrm{ml} \mathrm{L}$-broth supplemented with thiamin, ampicillin and kanamycin. Plasmid DNA was isolated from $0.5 \mathrm{ml}$ of the above cultures by the rapid alkaline extraction method of Birnboim \& Doly (1979) and digested with 1-3 units of restriction endonuclease, as described by Lohmeier et al. (1981).

Membrane preparations and detergent extractions. Crude cell envelopes were prepared by French pressure cell lysis at $110 \mathrm{MPa}$ as described by Dickie \& Weiner (1979). Inner membranes were prepared by a modification of the method of Yamato et al. (1975). DNAase $\left(10 \mu \mathrm{g} \mathrm{ml}^{-1}\right)$ and $\mathrm{MgCl}_{2}(25 \mathrm{mM})$ were added before lysis in $50 \mathrm{mM}$ Tris/ $\mathrm{HCl}, \mathrm{pH} 7.5,50 \mathrm{mM}-\mathrm{NaCl}$ at $34 \mathrm{MPa}$. At the final step, isolated inner membranes were resuspended in a minimum volume of $200 \mathrm{mM}$-sodium phosphate buffer, $\mathrm{pH} 6 \cdot 8$. Detergent extracts were prepared by suspension of inner membranes ( $10 \mathrm{mg}$ protein $\mathrm{ml}^{-1}$ ) in $200 \mathrm{~mm}$-sodium phosphate buffer, $\mathrm{pH} 6.8,1 \%(\mathrm{v} / \mathrm{v})$ Triton X-100. The extract was stirred on ice for $1 \mathrm{~h}$. Insoluble debris was removed by centrifugation for $5 \mathrm{~min}$ at $15000 \mathrm{~g}$. All solutions contained $2 \mathrm{mM}$-phenylmethylsulphonyl fluoride and, unless otherwise stated, all procedures were done at between 0 and $4^{\circ} \mathrm{C}$.

Assays. Fumarate reductase was assayed by the method of Dickie \& Weiner (1979) except that the assay buffer was $200 \mathrm{~mm}$-sodium phosphate, $\mathrm{pH} 6.8,0.5 \mathrm{mM}$-DTT. For anion titrations this buffer was changed to $25 \mathrm{mM}$ HEPES/ $\mathrm{NaOH}, \mathrm{pH} 6 \cdot 8,0.5 \mathrm{~mm}-\mathrm{DTT}$. One unit of activity equals $1 \mu$ mol reduced benzyl viologen oxidized $\mathrm{min}^{-1}$. Proteins were estimated by the method of Bradford (1976) using crystalline bovine serum albumin (BioRad) as standard.

Quinol oxidase activity was measured in $4 \mathrm{ml}$ quartz cuvettes sealed with rubber septa. All buffers and solutions were degassed and saturated with $\mathrm{O}_{2}$-free $\mathrm{Ar}$, and injected through the septa using Hamilton syringes. 2,3Dimethyl-1,4-naphthoquinone ( $5 \mathrm{~mm}$ in ethanol) was reduced by the addition of $2 \mathrm{~mol} \mathrm{NaBH}_{4}(28 \mathrm{~mm}$ in $0.025 \mathrm{M}$ $\mathrm{NaOH}) \mathrm{mol}^{-1}$ and kept dark and anoxic $\left(\mathrm{DMNH}_{2}\right)$. The quinol could be kept stably reduced for at least $3 \mathrm{~h}$. Final substrate concentrations in $3.7 \mathrm{ml} 100 \mathrm{~mm}$-sodium phosphate, $\mathrm{pH} 6.8$, assay buffer were $50 \mu \mathrm{M}-\mathrm{DMNH}_{2}$ and 


\section{Table 1. Bacterial strains, phage and plasmids}

Bacteria

E. coli $\mathrm{HBl} 01$

E. coli MI1443

Phage and plasmids

$\lambda b 221$ c1857rex $:: \operatorname{Tn} 5$
pBR322
pFRD1 17
pFRD79
pFRD79 $:: \operatorname{Tn} 5-233$
pFRD79 : $: \operatorname{Tn} 5-239$
pFRD79 $:: \operatorname{Tn} 5-260$
pFRD79 : $\operatorname{Tn} 5-299$

Genotype/phenotype

$\mathrm{F}^{-}$hsdR hsdM pro

leu gal lac thi recA rps $L$

$\triangle\left(\right.$ frd $A B C D$ ampC) $\mathrm{Sm}^{r}$
Source

G. McFadden, University

of Alberta, Canada

M. Iwaya, University

of Kentucky, USA

$200 \mu \mathrm{M}$-sodium fumarate. Oxidation of $\mathrm{DMNH}$, was followed at $270 \mathrm{~nm}$, using an absorption coefficient of 16000 $1 \mathrm{~mol}^{-1} \mathrm{~cm}^{-1}$

$S D S-P A G E$. Gels $(22 \times 15 \times 0.15 \mathrm{~cm})$ were linear gradients of $12-17 \%(\mathrm{w} / \mathrm{v})$ acrylamide, $0.32-0 \cdot 45 \%(\mathrm{w} / \mathrm{v})$ bisacrylamide and $0-6 \%(\mathrm{w} / \mathrm{v})$ sucrose. All solutions were according to Laemmli (1970). Gels were stained and destained as described by Lemire et al. (1982).

Thermal stability studies. Fumarate reductase catalytic dimer or mutant enzymes were stored in 200 mm-sodium phosphate buffer, pH 6.8. Immediately before assay the buffer was exchanged by chromatography through $1 \mathrm{ml}$ Sephadex G-25 Fine columns equilibrated with $25 \mathrm{~mm}$ HEPES/NaOH, pH 6.8, and coloured fractions were pooled for assay. Membrane-bound forms were pelleted for $20 \mathrm{~min}$ at $103000 \mathrm{~g}$ in a Beckman Airfuge and resuspended by homogenization in $25 \mathrm{~mm}$-HEPES/ $\mathrm{NaOH}, \mathrm{pH} 6.8$. Incubations were done at $47^{\circ} \mathrm{C}$ for up to $60 \mathrm{~min}$ at a protein concentration of $1-3 \mathrm{mg} \mathrm{ml}^{-1}$. Samples were removed at intervals and assayed for fumarate reductase activity.

Anion titrations. Samples were prepared in $25 \mathrm{mM}-\mathrm{HEPES} / \mathrm{NaOH}, \mathrm{pH} 6.8$ as described for thermal stability studies. Enzymes were assayed as described above, in the presence of increasing concentrations of sodium phosphate buffer, pH 6.8.

${ }^{35} \mathrm{~S}$-Labelling. Stationary phase L-broth cultures $(2 \mathrm{ml})$ were washed with two $5 \mathrm{ml}$ volumes of $50 \mathrm{mM}-\mathrm{Tris} / \mathrm{HCl}$, $\mathrm{pH} 7 \cdot 2$, by centrifugation at $5000 \mathrm{~g}$ for $10 \mathrm{~min}$ followed by resuspension, and inoculated into $60 \mathrm{ml} \mathrm{M} 9 \mathrm{medium}$ supplemented with thiamin, kanamycin, ampicillin and $40 \mu \mathrm{g} \mathrm{ml}^{-1}$ each of 19 amino acids (lacking methionine). $\left.{ }^{35} \mathrm{~S}\right]$ Methionine $\left(1.0 \mathrm{MBq} ; 46.6 \mathrm{TBq} \mathrm{mol}^{-1}\right)$ was added and the culture grown anaerobically for $21 \mathrm{~h}$ at $37^{\circ} \mathrm{C}$.

Immunoprecipitations. FRDA and FRDB polypeptides were isolated by excision from Coomassie Blue stained SDS-PAGE gels. The polyacrylamide slices were finely minced and emulsified with Freund's complete adjuvant. Catalytic dimer was purified by phenyl-Sepharose chromatography (Dickie \& Weiner, 1979) and emulsified in Freund's complete adjuvant at $1 \mathrm{mg}$ protein $\mathrm{ml}^{-1}$. Rabbit antisera to FRDA, FRDB and purified catalytic dimer were raised by standard methods. Serum $\left(75 \mathrm{mg}\right.$ protein $\mathrm{ml}^{-1}$ ) was pretreated with $2 \mathrm{~mm} p$-tosyllysylchloromethyl ketone, $p$-tosylphenylalanylchloromethyl ketone and benzamidine hydrochloride, $1 \mathrm{U}$ aprotinin $\mathrm{ml}^{-1}$ and $0 \cdot 1 \mathrm{vol}$. cytoplasmic extract from a culture not expressing fumarate reductase. After incubation for $2 \mathrm{~h}$ at room temperature the serum was cleared by centrifugation at $20000 \mathrm{~g}$ for $20 \mathrm{~min}$. Cleared antiserum or control IgG (15 mg rabbit anti-succinyl-CoA synthetase $\mathrm{ml}^{-1}$ ) was mixed $5: 1$ with unlabelled or ${ }^{35} \mathrm{~S}$-labelled cytoplasmic fraction $\left(20-25 \mathrm{mg} \mathrm{ml}^{-1}\right)$ and incubated $5 \mathrm{~h}$ at $4{ }^{\circ} \mathrm{C}$. Bovine serum albumin $\left(0.2 \mathrm{mg} \mathrm{ml}^{-1}\right)$ was added to the ${ }^{35} \mathrm{~S}$-labelled samples. Unlabelled immunoprecipitates were harvested by centrifugation at $13000 \mathrm{~g}$ for $5 \mathrm{~min}$, sonicated at $10 \mathrm{~mW}$ for $60 \mathrm{~s}$ in 5 vols $10 \mathrm{mM}$-sodium phosphate/potassium phosphate-buffered isotonic saline, pH 7.4 (PBS), $0.5 \% \mathrm{C}_{12} \mathrm{E}_{8}$ (octaethyleneglycol monododecyl ether; Nikko Chemicals, Tokyo, Japan) and repelleted as before. For labelled samples, Staphylococcus aureus protein A was added to $0 \cdot 1 \mathrm{mg} \mathrm{ml}^{-1}$ and incubated a further $2 \mathrm{~h}$ at $4{ }^{\circ} \mathrm{C}$. The co-precipitates were collected as above. The pellets were homogenized in $25 \mu \mathrm{l} \mathrm{PBS}, 25 \mu \mathrm{l}$ solubilization buffer (Laemmli, 1970) and boiled for $2 \mathrm{~min}$.

Immunoblotting analysis. Gels were prepared as described above in slabs of $11 \times 15 \times 0 \cdot 15 \mathrm{~cm} ; 10 \mu \mathrm{g}$ protein was loaded per well. Protein was transferred to BA85 nitrocellulose paper by passive diffusion (Renart et al., 1979; Bowen et al., 1980) for $24 \mathrm{~h}$. The nitrocellulose-bound protein was decorated by the method of Johnson et al. (1984) with rabbit antisera raised against FRDA or FRDB. Bands were visualized with horseradish peroxidase-coupled goat-antirabbit antibody (BioRad). 
(b)

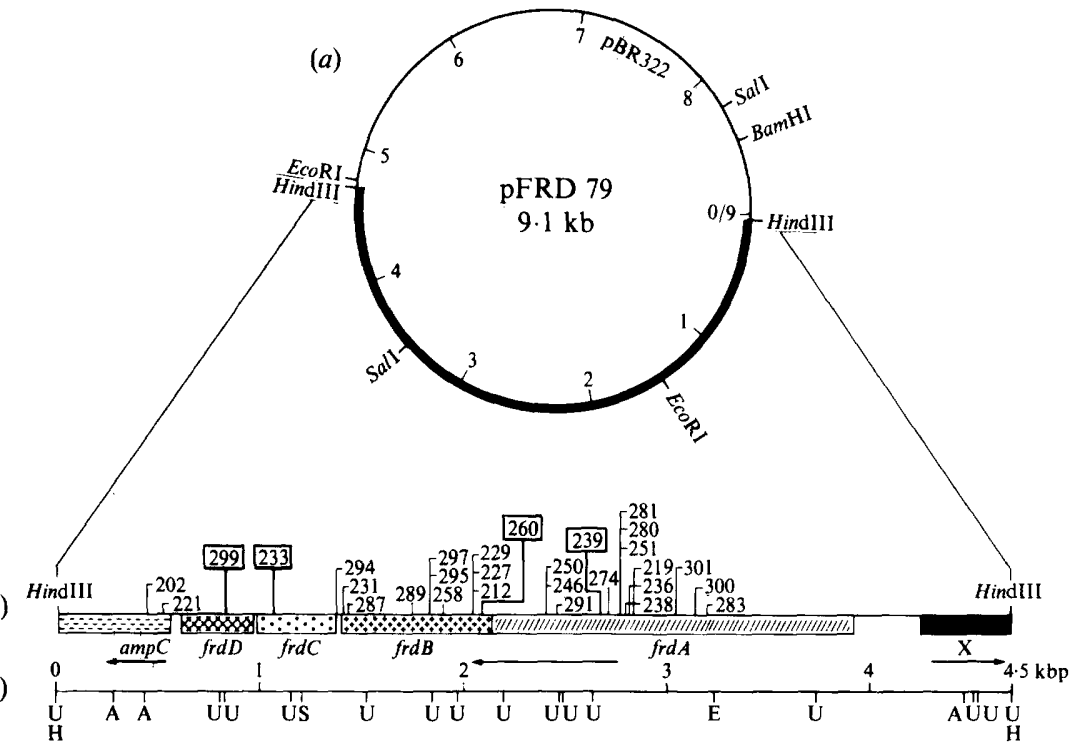

Fig. 1. (a) Restriction map of pFRD79.

, HindIII fragment carrying frd;

,pBR322. (b)

Genetic map of $H$ indIII fragment: arrows show direction of transcription; numbers mark locations of Tn5 insertions. (c) Restriction map of HindIII fragment: A, AvaI; E, EcoRI; H, HindIII; S, Sall; U, AluI.

\section{RESULTS}

\section{Isolation of Tn5 insertion mutations}

A total of 302 colonies exhibiting both ampicillin and kanamycin resistance were screened. The EcoRI restriction digestion patterns were compared to that of the parent plasmid pFRD79 (Fig. 1 a). Loss of the $3.4 \mathrm{kbp}$ fragment and appearance of a $9 \mathrm{kbp}$ fragment indicated insertion of Tn 5 into the frd operon distal to the EcoRI site in $f r d A: 72$ colonies $(23.8 \%)$ showed this pattern. An additional $112(37 \cdot 1 \%)$ colonies showed a pattern consistent with $\operatorname{Tn} 5$ insertions in the pBR322 vector or the promoter-proximal region of frdA, while the remainder $(39.1 \%)$ showed a pattern which indicated the presence of both a wild-type pFRD79 and a transposoncarrying plasmid.

The location of the Tn 5 insertion in the frd operon was mapped for each of the $72 \mathrm{frd}:: \operatorname{Tn} 5$ plasmids by digestion with $S a / I, B a m H I$ and HindIII. Insertions in the frdCD region were further mapped with $A v a$ I and $A / u$ I digestions (Fig. 1 c). Of the insertions $37(51.4 \%$ ) mapped in frd $A, 28(38.9 \%)$ in $f r d B, 3(4.2 \%)$ in $f r d C$ and one $(1.4 \%)$ in $f r d D$. An additional $2(2.8 \%)$ were in the $a m p C$ region (Fig. $1 b$ ). Mutant pFRD79::Tn5-239 was chosen as an insertion in frdA (frd $A:: \operatorname{Tn} 5)$, pFRD79::Tn5-260 as an insertion in $f r d B(f r d B:: \operatorname{Tn} 5), \mathrm{pFRD} 79:: \operatorname{Tn} 5-233$ as an insertion in frd $C$ ( frdC::Tn5), and pFRD79::Tn5-299 as the sole example of an insertion in frdD (frdD: : Tn 5$)$.

\section{Expression of fumarate reductase polypeptides by frd mutations}

Each of the selected frd mutations was examined for expression and cellular localization of FRD polypeptides. When $\operatorname{Tn} 5$ was inserted within $\operatorname{frd} A($ frd $A:: \operatorname{Tn} 5)$ no fumarate reductase subunits were detected in the cytoplasm by immunoprecipitation (Fig. 2a, lane 1), or immunoblotting (Fig. $3 a$, lanes 1 and 2). Similar results were seen with other $\operatorname{Tn} 5$ insertions in frdA. Following insertion of Tn 5 within $\operatorname{frdB}(\operatorname{frdB}:: \operatorname{Tn} 5)$, intact FRDA was detected by immunoblotting (Fig. $3 a$, lanes 1 and 3 ) and by immunoprecipitation (Fig. 2a, lane 2), but no fragments of FRDB were seen (Fig. $3 b$, lanes 1 and 3). The antibodies raised against FRDB exhibited some cross-reactivity with FRDA (Fig. 3b, lanes 1 and 3). The FRDA polypeptide 


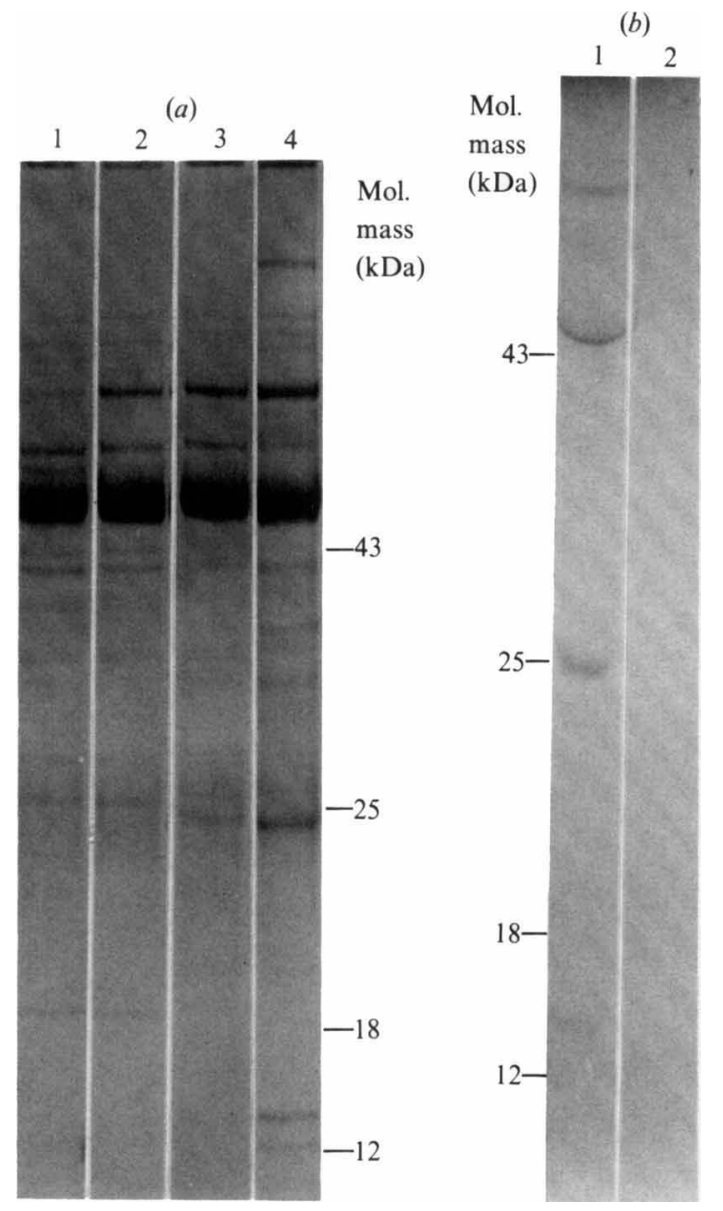

Fig. 2. (a) SDS-PAGE of unlabelled immunoprecipitates, Coomassie Blue staining. Cytoplasmic fractions and Triton X-100 extracted inner membranes were precipitated with anti-FRDAB serum and electrophoresed as described in Methods. Lane 1, HB101(frdA : :Tn5) cytoplasmic fraction; lane 2, HB101(frdB: :Tn5) cytoplasmic fraction; lane 3, HBI01(frdC::Tn5) cytoplasmic fraction; lane 4, HB101(frdD::Tn5) Triton X-100 extract. (b) SDS-PAGE of ${ }^{35}$ S-labelled immunoprecipitates, autoradiograph. Lane 1, MI1443(frdD::Tn5) cytoplasmic fraction precipitated with anti-FRDAB serum; lane 2, MI1443(frdD::Tn5) cytoplasmic fraction precipitated with control immunoglobulin. Molecular mass markers are chick ovalbumin ( $43 \mathrm{kDa}), \alpha$-chymotrypsinogen $(25 \mathrm{kDa}), \beta$-lactoglobulin $(18 \mathrm{kDa})$ and cytochrome $c(12 \mathrm{kDa})$.

accumulated in the cytoplasm and contained the covalent flavin cofactor characteristic of fumarate reductase (Weiner \& Dickie, 1979) (data not shown). When Tn5 was inserted near the middle of frdC ( $\mathrm{r} d C:: \mathrm{Tn} 5$ ), both FRDA and FRDB accumulated in the cytoplasm (Fig. $2 a$, lane 3) but a FRDC fragment could not be detected on the gels. The insertion mutation in frdD ( $f r d D:: \operatorname{Tn} 5$ ) gave rise to a unique phenotype. Immunoprecipitation of Triton X-100 extracts of the inner-membrane fraction indicated that a tetramer consisting of FRDA, B, C and a truncated FRDD migrating at an apparent molecular mass of $12 \mathrm{kDa}$ was amplified in the membrane (Fig. $2 a$, lane 4). No wild-type FRDD could be visualized in the membrane fraction. Furthermore, examination of Fig. $2 b$, lane 1 shows that a fumarate reductase trimer composed of FRDA, B and C accumulated in the cytoplasm of a strain which does not carry a chromosomal copy of frd (MI1443, Table 1). This trimer apparently reacted poorly with the antisera available, and could only be visualized in radiolabelled immunoprecipitates. 
(a)

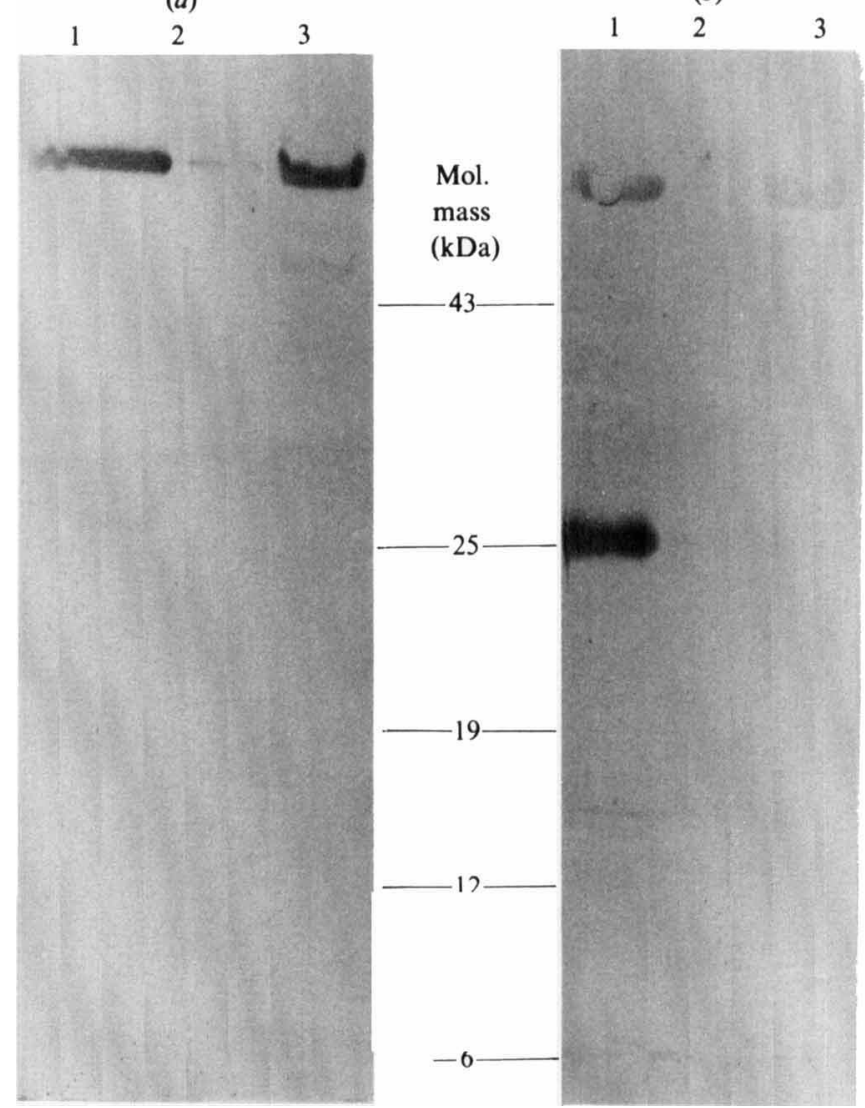

Fig. 3. Immunoblotting analysis of fumarate reductase polypeptides. Immunoblotting was done as described in Methods. In ( $a$ ) anti-FRDA gamma-globulin was used; in $(b)$ anti-FRDB gamma-globulin was used. Lane 1 SDS-solubilized membranes from HB101(pFRD79); Lane 2 cytoplasm from HB101( frd A : :Tn 5); Lane 3 cytoplasm from HB 101(frdB : :Tn 5). Molecular weight markers are chick ovalbumin $(43 \mathrm{kDa}), \alpha$-chymotrypsinogen $(25 \mathrm{kDa}), \beta$-lactoglobulin $(18 \mathrm{kDa})$ and cytochrome $c$ $(12 \mathrm{kDa})$.

\section{Amplification of fumarate reductase activity in frd mutations}

The presence of a complete frd operon on a plasmid vector (pFRD79) results in an amplification of membrane-bound fumarate reductase activity over wild-type (Table 2). The presence of a plasmid carrying only frd $A$ and $f r d B$ (pFRD117) results in a substantial expression of soluble activity. Insertion of a transposon into frdA or $f r d B$ did not give rise to detectable activity in the cytoplasm, but normal levels of activity were observed in the cytoplasmic membrane of $E$. coli HB101, due to the intact chromosomal copy of frd. HB101 harbouring mutation $f r d C:: \operatorname{Tn} 5$ produces large quantities of soluble, cytoplasmic enzyme activity and normal levels of membrane-associated activity. Phenotypically, this plasmid is indistinguishable from pFRD117 (Lemire et al., 1982).

In transposon mutation $f r d D:: \operatorname{Tn} 5$ both the cytoplasmic and membrane fractions of HB101 had amplified levels of fumarate reductase activity. Nearly $80 \%$ of the total activity was soluble, while the remainder was bound to the inner membrane (Table 2).

Properties of fumarate reductase produced in strains harbouring frdC : :Tn 5 and frdD : :Tn5

The catalytic dimer and holoenzyme forms of fumarate reductase can be easily distinguished (Lemire et al., 1982; Weiner et al., 1984). E. coli MI1443 is deleted for frd and ampC and cannot 


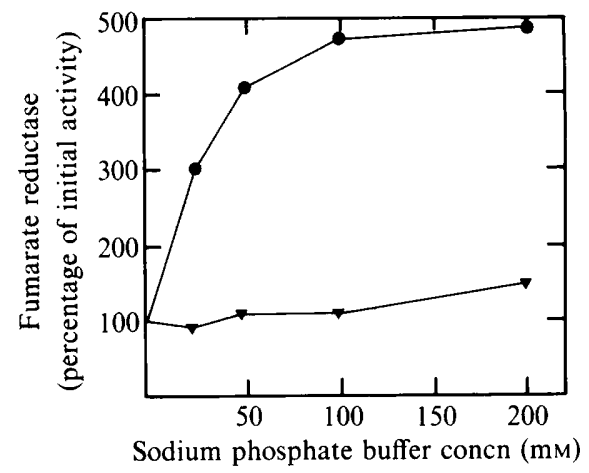

Fig. 4. Anion titration of the cytoplasmic fumarate reductase activity produced by HB101(frdC::Tn 5$)$ (O) and HB10l(frdD:: Tn5) ( $)$. Assays were done in $25 \mathrm{~mm}-\mathrm{HEPES} / \mathrm{NaOH}, \mathrm{pH} 6.8,0.5 \mathrm{~mm}-\mathrm{DTT}$, with increasing concentrations of sodium phosphate buffer, $\mathrm{pH} 6.8$.

Table 2. Expression and localization of fumarate reductase

Cells were grown as described in Methods and lysed by two passages through a French pressure cell. Crude envelopes were separated from cytoplasm by centrifugation at $150000 \mathrm{~g}$ for $60 \mathrm{~min}$ and the envelopes resuspended by homogenization in a minimal volume of $200 \mathrm{~mm}$-sodium phosphate buffer, pH 6.8. Data are representative of four independent experiments.

\begin{tabular}{|c|c|c|c|c|}
\hline \multirow[b]{2}{*}{ Strain } & \multicolumn{2}{|c|}{$\begin{array}{c}\text { Specific activity } \\
\text { [units (mg protein) })^{-1} \text { ] }\end{array}$} & \multicolumn{2}{|c|}{$\begin{array}{l}\text { Percentage of } \\
\text { total activity }\end{array}$} \\
\hline & Envelopes & Cytoplasm & Envelopes & Cytoplasm \\
\hline $\mathrm{HB} 101 / \mathrm{pBR} 322$ & 21 & ND & 100 & ND \\
\hline $\mathrm{HB} 101 / \mathrm{pFRD} 117$ & $11 \cdot 5$ & $42 \cdot 3$ & $0 \cdot 6$ & $99 \cdot 4$ \\
\hline HB101/pFRD79 & $76 \cdot 7$ & $3 \cdot 2$ & 56.8 & $43 \cdot 2^{*}$ \\
\hline HB $101 / f r d C:: \operatorname{Tn} 5$ & 19 & $70 \cdot \overline{8}$ & 0.9 & $99 \cdot 1$ \\
\hline HB $101 / f r d A:: \operatorname{Tn} 5$ & 16 & ND & 100 & ND \\
\hline $\mathrm{HB} 101 / f r d B:: \operatorname{Tn} 5$ & 12 & ND & 100 & ND \\
\hline $\mathrm{HB} 101 / f r d D:: \operatorname{Tn} 5$ & 45 & $32 \cdot 7$ & $21 \cdot 5$ & $78 \cdot 5$ \\
\hline
\end{tabular}

ND, Not detected.

* Fumarate reductase in the cytoplasm of this strain is not soluble. It is a holoenzyme bound into tubular lipoprotein structures induced by over-expression of the enzyme (Weiner et al., 1984).

grow anaerobically on GF. pFRD117, which produces dimer, does not permit growth on GF, while pFRD79, which codes for wild-type tetramer, does (C. Condon \& J. H. Weiner, unpublished observation). The activity of the dimer, but not the tetramer, is stimulated fivefold by addition of anions to the assay buffer (Robinson \& Weiner, 1981). Additionally, the catalytic dimer is rapidly denatured by incubation in alkaline solution $(\mathrm{pH} 8 \cdot 6)$ or at elevated temperature $\left(>45^{\circ} \mathrm{C}\right)$. Holoenzyme, but not dimer, is capable of accepting reducing equivalents from quinone analogues (Cecchini et al., 1986; Weiner et al., 1986). These observations have led to the proposal that the anchor polypeptides (FRDC and FRDD) induce an optimal conformation of the catalytic subunits (Weiner et al., 1984) and are essential for the physiological functions of fumarate reductase. The properties of the two Tn 5 insertions in FRDC and D provide further evidence for this model.

Transposon mutation frdC::Tnj produced catalytic dimer in the cytoplasm, while frdD ::Tn 5 produced soluble trimer. These two enzyme forms showed different anion dependence. frd $C:: \operatorname{Tn} 5$ enzyme was stimulated fivefold by anions (Fig. 4), as expected for catalytic dimer and in agreement with the results reported previously (Lemire et al., 1982). frdD : :Tn 5 trimeric enzyme was not activated by anions. This result indicates that although the frd $D:: \operatorname{Tn} 5$ enzyme lacked FRDD, it behaved like tetramer with respect to anion dependence. 


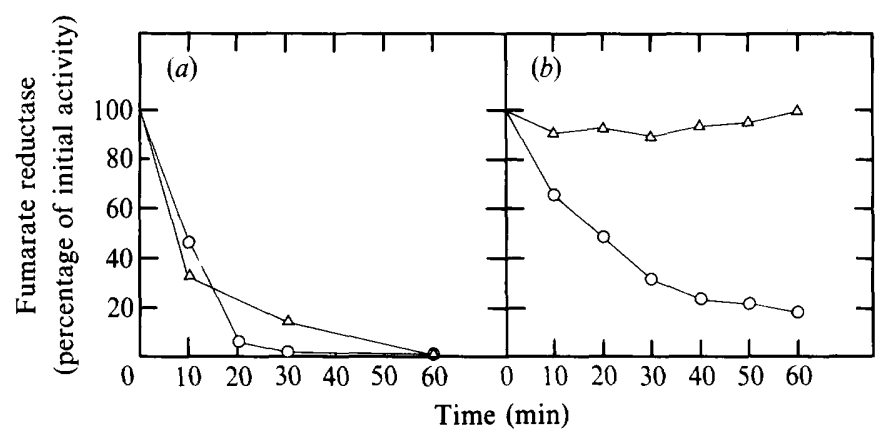

Fig. 5. (a) Thermal stability $\left(47^{\circ} \mathrm{C}, \mathrm{pH} 6.8\right)$ of the cytoplasmic fumarate reductase activity produced by $\mathrm{HB} 101($ frdC $:: \operatorname{Tn} 5)(O)$ and $\mathrm{HB} 101($ frdD : :Tn 5$)(\triangle) ;(b)$ alkaline stability $\left(\mathrm{pH} 8 \cdot 6,24^{\circ} \mathrm{C}\right)$ of the cytoplasmic fumarate reductase activity produced by $\mathrm{HB} 101(f r d C:: \operatorname{Tn} 5)(\mathrm{O})$ and $\mathrm{HB} 101(f r d D:: \operatorname{Tn} 5)$ $(\triangle)$. Samples were treated and assays were done as described in Methods.

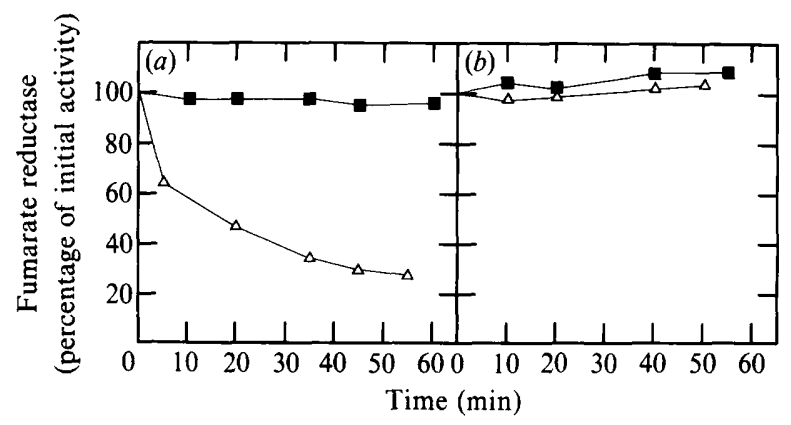

Fig. 6. (a) Thermal stability $\left(47^{\circ} \mathrm{C}, \mathrm{pH} 6.8\right)$ of inner-membrane-bound enzyme produced by HB10l(pFRD79) $(\square)$ or by HB10l(frdD::Tn5) $\triangle$ ); (b) alkaline stability (pH 8.6, $24^{\circ} \mathrm{C}$ ) of innermembrane-bound enzyme produced by HBI01(pFRD79) $(\square)$ or by HB101(frdD::Tn5) $\triangle$ ).

To examine this further the thermal and alkaline labilities of the frdC::Tn 5 and $f r d D:: \operatorname{Tn} 5$ activities from the cytoplasm and $f r d D::$ Tn 5 activity from the membrane were measured. Both cytoplasmic enzymes were denatured by incubation at $47^{\circ} \mathrm{C}$ with a half-life of about $7 \mathrm{~min}$ (Fig. $5 a$ ). The $f r d C:: \operatorname{Tn} 5$ dimer was rapidly denatured by incubation at $\mathrm{pH} 8.6$ (Fig. $5 b$ ) while the frdD: :Tn 5 trimer was stable. The $f r d D:: \operatorname{Tn} 5$ tetramer in the inner membrane has stability properties comparable to those of the soluble trimer. It is thermolabile (Fig. $6 a$ ), unlike wildtype tetramer and stable to alkaline conditions (Fig. $6 b$ ).

The frdD::Tn5 plasmid complements MI1443 to growth on GF. The trimeric enzyme has no detectable fumarate reductase activity in the $\mathrm{DMNH}_{2}$ assay, while membrane-bound FRDABCD' has 2-(n-heptyl)-4-hydroxyquinoline- $N$-oxide-sensitive fumarate-dependent $\mathrm{DMNH}_{2}$ oxidase activity. The ratio of specific activity of the benzyl viologen to $\mathrm{DMNH}_{2}$ assays is nine for the two membrane-bound enzymes. Thus, the altered tetramer with the truncated FRDD subunit retains physiological activity, while the soluble FRDABC trimer does not. Together these results discriminate the functions of FRDC and FRDD.

\section{DISCUSSION}

Seventy two Tn 5 insertions ( $23.8 \%$ of the total) in the $\mathrm{rrd}$ operon distal to the EcoRI site in frdA were isolated. If $\operatorname{Tn} 5$ transposed completely at random, $37 \%$ of insertions would be expected to lie in this $3.4 \mathrm{kbp}$ region of pFRD79 (9.1 kbp total size). While the transposition of Tn5 is not site-specific (Shaw \& Berg, 1979; Berg et al., 1980; Miller et al., 1980), there is a preference for insertion at GC (Berg et al., 1983). Moreover, it was shown that there is a hotspot 
for insertion of $\mathrm{Tn} 5$ at nucleotide 31 of pBR322, which is part of the HindIII site into which frd is cloned in pFRD79. This may account for the apparent bias for insertion in the vector compared to $\mathrm{frd}$. Bossi \& Ciampi (1981) reported that Tn 5 inserts preferentially at a concensus sequence which is homologous to a $12 \mathrm{bp}$ region in the terminal repeats of the transposon. The frd sequence has been computer-searched for this concensus sequence, and while it was found seven times when four mismatches were allowed, the locations did not match any of the insertions mapped (V. Paetkau, personal communication). The selectivity of $\mathrm{Tn} 5$ insertion is exemplified in Fig. 1, which shows a striking paucity of insertions within the frdCD region, compared to flanking sequences. The length of DNA coding for the small polypeptides and FRDB is similar, yet 28 insertions were mapped in $f r d B$ and only four in the $C D$ region. A possibility which cannot be ruled out at this time is that insertions did occur in this region, but the resulting mutations were lethal.

Expression analysis of a number of insertions within frd $A$ and $\operatorname{frd} B$ indicated that truncated fragments were never detected by the methods used. One possibility is that the cell recognized these aberrant polypeptides and rapidly cleared them by proteolysis (Goldberg, 1972). Truncated fragments of succinate dehydrogenase flavoprotein and iron-sulphur protein subunits have been detected in the cytoplasm of Bacillus subtilis, but they are unstable unless special precautions are taken to preserve them (Hederstedt, 1983; Hederstedt et al., 1985). Intact FRDA accumulated in the cytoplasm of strains carrying Tn 5 mutations in $f r d B$, although neither fumarate reductase (fumarate-dependent benzyl viologen oxidase) activity (Table 2) nor succinate dehydrogenase [succinate-dependent 3-(4,5-dimethylthiazolyl-2)-2,5-diphenyltetrazolium bromide (MTT) reductase] activity (data not shown) was observed. This is in agreement with the results of Cecchini et al. (1986), who also showed that the FRDA subunit was inactive as succinate dehydrogenase, but in contrast to the results reported by Unden \& Kröger (1981) for the fumarate reductase of Wolinella succinogenes. They observed that the isolated $79 \mathrm{kDa}$ covalent-flavin-containing subunit (equivalent to $E$. coli FRDA) was catalytically active, but only when associated as a homodimer. The monomer itself was inactive. This leads to the suggestion that the minimal catalytic unit for the $E$. coli enzyme is the FRDAB dimer.

It was previously shown that FRDC plus FRDD anchor and stabilize the catalytic dimer and permit fumarate-dependent oxidation of quinone analogues (Cecchini et al., 1986; Weiner et al., 1986). However, although these two subunits appear structurally similar (Weiner et al., 1984) no information has been available as to why two different polypeptides are needed. The Tn5 insertion in $f r d D$ addresses this question. The FRDABC trimer found in the cytoplasm of strains harbouring the frdD::Tn 5 plasmid has properties intermediate between those of dimer and tetramer. The presence of FRDC confers stability at high $\mathrm{pH}$, but not at high temperature. It renders the catalytic domain insensitive to anion stimulation by phosphate. It is not sufficient to allow binding of fumarate reductase to the inner membrane. It does not allow fumaratedependent oxidation of quinone analogues.

The membrane-bound mutant tetramer expressed by the $f r d D:: \operatorname{Tn} 5$ plasmid elucidates the role of FRDD. The truncated FRDD (FRDD') is capable of allowing membrane insertion of the complex, but at an apparently reduced efficiency $(21.5 \%$ membrane-bound in $f r d D:: \operatorname{Tn} 5$ vs $100 \%$ membrane-bound in pFRD79; Table 2). This effect could also be due to competition between proteolysis of the FRDD' fragment, giving rise to soluble trimer, and insertion of the mutant tetrameric complex into the membrane (Oliver, 1985). It has already been noted that intact FRD subunits tend to accumulate, while truncated polypeptides do not. FRDD' does not confer thermal stability on the catalytic domain, implicating the missing $\mathrm{C}$-terminal fragment in this role. FRDD', together with FRDC, permit the use of quinone analogues as reducing agents and apparently normal physiological activity of the fumarate reductase complex. It cannot be distinguished whether FRDD' alone is responsible, or the interaction between it and the rest of the subunits forms the site of interaction with the quinones of the electron transport chain.

It is interesting to note that in strains bearing the $f r d D:: \operatorname{Tn} 5$ plasmid there is only trimer in the cytoplasm and only tetramer in the cytoplasmic membrane. It is inferred from this that FRDA and B are assembled from a cytoplasmic pool, and that the hydrophobic FRDC polypeptide can associate with this dimer in a soluble form. On addition of the FRDD (or 
FRDD') polypeptide the complex becomes membrane bound, but the order of subunit assembly or membrane insertion remains unclear. It is not known why this putative assembly pathway produces only mutant tetramer in a strain that harbours both frdD::Tn 5 and a wild-type frd operon ( $\mathrm{HB101}$ ), unless overproduction of mRNA from the multicopy plasmid overwhelms that from the chromosome. Experiments to further elucidate this pathway and the role of FRDC and FRDD in quinone binding are being done.

The authors wish to thank Dr M. Iwaya for supplying MI1443 and Dr G. D. Armstrong for assistance with raising antisera. This work was supported by grant MT-5838 from the Medical Research Council of Canada.

\section{REFERENCES}

BERG, D. E. (1977). Insertion and excision of the transposable resistance determinant $\mathrm{Tn} 5$. In $D N A$ Insertion Elements, Plasmids and Episomes, pp. 205212. Edited by A. I. Bukhan, J. A. Shappiro \& S. L. Adhya. Cold Spring Harbor, New York: Cold Spring Harbor Laboratory.

BERG, D. E., JoRgenson, R. \& Davies, J. (1978). Transposable kanamycin-neomycin resistance determinants. In Microbiology-1978, pp. 13-15. Edited by D. Schlesinger. Washington, DC: American Society for Microbiology.

Berg, D. E., Weiss, A. \& Crossland, L. (1980). Polarity of $\operatorname{Tn} 5$ insertion mutations in Escherichia coli. Journal of Bacteriology 142, 439-446.

Berg, D. E. Schmandt, M. A. \& Lowe, J. B. (1983). Specificity of transposon Tn 5 insertion. Genetics 105, 813-828.

Birnboim, H. C. \& Doly, J. (1979). A rapid alkaline extraction procedure for screening recombinant plasmid DNA. Nucleic Acids Research 7, 1513-1523.

Bossi, L. \& Ciampi, M. S. (1981). DNA sequences at the sites of three insertions of the transposable element Tn5 in the histidine operon of Salmonella. Molecular and General Genetics 183, 406-408.

Bowen, B., Steinberg, J., Laemmli, U. K. \& Weintraub, H. (1980). The detection of DNAbinding proteins by protein blotting. Nucleic Acids Research 8, 1-20.

BRADFORD, M. M. (1976). Sensitive method for the quantitation of microgram quantities of protein utilizing the principle of protein-dye binding. Analytical Biochemistry 72, 248-254.

Cammack, R., Patil, D. S. \& Weiner, J. H. (1986). Evidence that centre 2 in Escherichia coli fumarate reductase is a $[4 \mathrm{Fe}-4 \mathrm{~S}]$ cluster. Biochimica et biophysica acta 870, 538-544.

Cecchini, G., Ackrell, B. A. C., Deshler, J. O. \& Gunsalus, R. P. (1986). Reconstitution of quinone reduction and characterization of Escherichia coli fumarate reductase activity. Journal of Biological Chemistry 261, 1808-1814.

Clewell, D. B. \& Helinski, D. R. (1972). Effect of growth conditions on the formation of the relaxation complex of supercoiled ColE1 deoxyribonucleic acid and protein in Escherichia coli. Journal of Bacteriology 110, 1135-1146.

COLE, S. T. (1982). Nucleotide sequence coding for the flavoprotein subunit of the fumarate reductase of Escherichia coli. European Journal of Biochemistry 122, 479-484.
Cole, S. T., Grundström, T., Jaurin, B., Robinson, J. J. \& WEINER, J. H. (1982), Location and nucleotide sequence of $f r d B$, the gene coding for the iron-sulphur protein subunit of the fumarate reductase of Escherichia coli. European Journal of Biochemistry 126, 211-216.

Cole, S. T., Condon, C., Lemire, B. D. \& Weiner, J.H. (1986). Molecular biology, biochemistry and bioenergetics of fumarate reductase, a complex membrane-bound iron-sulfur flavoenzyme. Biochimica et biophysica acta 811, 381-403.

De Bruijn, F. J. \& Ausubel, F. M. (1981). The cloning and transposon $\operatorname{Tn} 5$ mutagenesis of the $g \ln A$ region of Klebsiella pneumoniae: identification of $g \ln R$, a gene involved in the regulation of the nil and hut operons. Molecular and General Genetics 183, 289297.

de Bruijn, F. J., Stroke, I. L., Marvel, D. J. \& Ausuber, F. M. (1983). Construction of a correlated physical and genetic map of the Klebsiella pneumoniae his $D G O$ region using transposon $\operatorname{Tn} 5$ mutagenesis. EMBO Journal 2, 1831-1838.

Dickie, P. \& WeIneR, J. H. (1979). Purification and characterization of membrane-bound fumarate reductase from anaerobically grown Escherichia coli. Canadian Journal of Biochemistry 57, 813-821.

GoldBerG, A. L. (1972). Degradation of abnormal proteins in Escherichia coli. Proceedings of the National Academy of Sciences of the United States of America 69, 422-426.

GRUNDSTRÖM, T. \& JAURIN, B. (1982). Overlap between ampC and frd operons on the Escherichia coli chromosome. Proceedings of the National Academy of Sciences of the United States of America 79, 11111115.

HADDOCK, B. A. \& Jones, C. W. (1977). Bacterial respiration. Bacteriological Reviews 41, 47-99.

Hederstedt, L. (1983). Succinate dehydrogenase mutants of Bacillus subtilis lacking covalently bound flavin in the flavoprotein subunit. European Journal of Biochemistry 132, 589-593.

Hederstedt, L., Maguire, J. J., Waring, A. J. \& OHNISHI, T. (1985). Characterization by electron paramagnetic resonance and studies on subunit location and assembly of the iron-sulfur clusters of Bacillus subtilis succinate dehydrogenase. Journal of Biological Chemistry 260, 5554-5562.

INGLEDEW, W. J. \& Poole, R. K. (1984). The respiratory chains of Escherichia coli. Microbiological Reviews 48, 222-271. 
Johnson, R. C., Yin, J. C. P. \& Reznikoff, W. S. (1982). Control of Tn 5 transposition in Escherichia coli is mediated by protein from the right repeat. Cell 30, 873-882.

Johnson, D. A., Gautsch, J. W., Sportsman, J. R. \& ELDER, J. H. (1984). Improved technique utilizing nonfat dry milk for analysis of proteins and nucleic acids transferred to nitrocellulose. Gene Analysis Techniques 1, 3-8.

LAEMMLI, U. K. (1970). Cleavage of structural proteins during the assembly of the head of bacteriophage T4. Nature, London 277, 680-685.

LAIRD, A. J. \& Young, I. G. (1980). Tn 5 mutagenesis of the enterochelin gene cluster of Escherichia coli. Gene 11, 359-366.

LEMIRE, B. D., RoBINSON, J. J. \& WeINER, J. H. (1982). Identification of the membrane anchor polypeptides of Escherichia coli. Journal of Bacteriology 152, 11261131.

Lemire, B. D., Robinson, J. J., Bradley, R. D., SCRABA, D. G. \& WeINER, J. H. (1983). Structure of fumarate reductase on the cytoplasmic membrane of Escherichia coli. Journal of Bacteriology 155, 391-397.

Lohmeier, E., Hagen, D. S., Dickie, P. \& Weiner, J. H. (1981). Cloning and expression of the fumarate reductase gene of Escherichia coli. Canadian Journal of Biochemistry 59, 158-164.

LuPSki, J. R., Smillie, B. L., Blattner, F. R. \& Godson, G. N. (1982). Cloning and characterization of the Escherichia coli chromosomal region surrounding the $\operatorname{dna} G$ gene, with a correlated physical and genetic map of dnaG generated via transposon Tn5 mutagenesis. Molecular and General Genetics 185, 120-128.

Mandel, M. \& Higa, A. (1970). Calcium dependent bacteriophage DNA infection. Journal of Molecular Biology 53, 159-162.

Miller, J. H. (ed) (1972). Experiments in Molecular Genetics, pp. 431-435. Cold Spring Harbor, New York: Cold Spring Harbor Laboratory.

Miller, J. H., Calos, M. P., Galas, D., Hofer, M., Buchel, D. E. \& Muller-Hill, B. (1980). Genetic analysis of transpositions in the lac region of Escherichia coli. Journal of Molecular Biology 144, 118.

Oliver, D. (1985). Protein secretion in Escherichia coli. Annual Reriew of Microbiology 39, 615-648.

Pannekoek, H., Hillie, J \& NoOrdermeer, I. (1980). Relief of polarity caused by transposon $\operatorname{Tn} 5$ : application in mapping a cloned region of the Escherichia coli uerB locus essential for UV resistance. Gene 12, 51-61.
Renart, J., Reiser, J. \& Stark, G. R. (1979). Transfer of proteins from gels to diazobenzyloxymethyl-paper and detection with antisera: a method for studying antibody specificity and antigen structure. Proceedings of the National Academy of Sciences of the United States of America 76, 3116-3120.

Robinson, J. J. \& WEINER, J. H. (1981). The effects of anions on fumarate reductase isolated from the cytoplasmic membrane of Escherichia coli. Biochemical Journal 199, 473-477.

Robinson, J. J. \& Weiner, J. H. (1982). Molecular properties of fumarate reductase isolated from the cytoplasmic membrane of Escherichia coli. Canadian Journal of Biochemistry 60, 811-816.

SHAw, K. J. \& BERG, C. M. (1979). Escherichia coli K 12 auxotrophs induced by insertion of the transposable element Tn5. Genetics 92, 741-747.

Singh, A. P. \& BragG, P. D. (1975). Reduced nicotinamide adenine dinucleotide dependent reduction of fumarate coupled to membrane energization in a cytochrome deficient mutant of Escherichia coli K 12. Biochimica et biophysica acta 396, 229-241.

Spencer, M. E. \& Guest, J. R. (1974). Proteins of the inner membrane of Escherichia coli: changes in composition associated with anaerobic growth and fumarate reductase amber mutation. Journal of Bacteriology 117, 954-959.

UNDEN, G. \& KRöGER, A. (1981). The function of the subunits of the fumarate reductase complex of Vibrio succinogenes. European Journal of Biochemistry 120, $577-584$.

Weiner, J. H. \& Dickie, P. (1979). Fumarate reductase of Escherichia coli. Elucidation of the covalent flavin component. Journal of Biological Chemistry 254, 8590-8593.

Weiner, J. H., Lemire, B. D., Elmes, M. L., Bradley, R. D. \& SCRABA, D. G. (1984). Overproduction of fumarate reductase in Escherichia coli induces a novel intracellular lipid-protein organelle. Journal of Bacteriology 158, 590-596.

Weiner, J. H., Cammack, R., Cole, S. T., Condon, C., Honoré, N., Lemire, B. D. \& Shaw, G. (1986). A novel mutant of Escherichia coli fumarate reductase decoupled from electron transport. Proceedings of the National Academy of Sciences of the United States of America 83, 2056-2060.

Yamato, I., AnrakU, Y. \& Hirosawa, K. (1975). Cytoplasmic membrane vesicles of Escherichia coli. I. A simple method for preparing the cytoplasmic and outer membranes. Journal of Biochemistry 77 , 705-718. 